Article

\title{
Reuse and Upcycling of Municipal Waste for ZEB Envelope Design in European Urban Areas
}

\author{
Elisa Pennacchia ${ }^{1}$, Mariagrazia Tiberi ${ }^{1}$, Elisa Carbonara ${ }^{1}$, Davide Astiaso Garcia ${ }^{1, *}$ and \\ Fabrizio Cumo ${ }^{2}$ \\ 1 Department of Astronautical, Electrical and Energy Engineering (DIAEE), Sapienza University of Rome, \\ Via Eudossiana 18, Rome 00184, Italy; elisa.pennacchia@uniroma1.it (E.P.); \\ mariagrazia.tiberi@uniroma1.it (M.T.); elisa.carbonara@uniroma1.it (E.C.) \\ 2 Department of Planning, Design, and Technology of Architecture (DPDTA), Sapienza University of Rome, \\ Via Flaminia 72, Rome 00196, Italy; fabrizio.cumo@uniroma1.it \\ * Correspondence: davide.astiasogarcia@uniroma1.it; Tel.: +39-349-230-3498
}

Academic Editors: Francesco Asdrubali and Pietro Buzzini

Received: 16 May 2016; Accepted: 24 June 2016; Published: 29 June 2016

\begin{abstract}
Building energy efficiency and urban waste management are two focal issues for improving environmental status and reducing greenhouse gas emissions. The main aim of this paper is to compare economic costs of new building envelope structures designed by authors reusing and upcycling municipal waste in order to decrease energy demand from the building sector and, at the same time, improve eco-friendly waste management at the local scale. The reuse of waste for building envelope structures is one of the main principles of the Earthship buildings model, based on the use of passive solar principles in autonomous earth-sheltered homes. This Earthship principle has been analyzed in order to optimize buildings' energy performance and reuse municipal waste for new building envelope structures in urban areas. Indeed, the elaborated structures have been designed for urban contexts, with the aim of reuse waste coming from surrounding landfills. The methods include an analysis of thermal performance of urban waste for designing new building envelope structures realized by assembling waste and isolating materials not foreseen in Earthship buildings. The reused materials are: cardboard tubes, automobile tires, wood pallets, and plastic and glass bottles. Finally, comparing economic costs of these new building envelope structures, the obtained results highlight their economic feasibility compared to a traditional structure with similar thermal transmittance.
\end{abstract}

Keywords: zero energy building; reuse municipal waste; energy efficiency; cost analysis

PACS: J0101

\section{Introduction}

The building sector is responsible for almost $40 \%$ of the energy consumption and greenhouse gas emissions in EU countries [1]; therefore, improving buildings' energy efficiency is a focal target for reaching EU decarbonization goals, starting from the 2020 climate and energy package and continuing with the 2030 climate and energy framework until the 2050 energy roadmap.

In Italy, due to the huge number town of centers and medieval villages under historical constraints, national targets could be reached both by designing eco-friendly new buildings and planning retrofitting interventions able to increase the energy efficiency of existing buildings [2].

The European Energy Performance of Buildings Directive (EPBD) states that by the end of 2020, all new constructions should be nearly zero-energy buildings (ZEB); that goal is anticipated in 2018 for the public sector. The nearly ZEB concept was indeed mentioned in the EPBD for describing an energy efficient building with a low energy demand that is mainly covered by on-site-generated renewable 
energy. In order to reach these targets, many strategies and technologies have been adopted using renewable energy sources [3] and combined heat and power systems [4-9].

ZEB definitions are generally based on the energy amount consumed yearly by the building for its operation [10]. The first idea of ZEB was born in the 1970s with an experimental Zero Energy House, constructed by the Technical University of Denmark [11].

Considering the regulatory framework for the reuse and upcycling of waste, the European Union legislation directly promotes and incentivizes reuse and recycling efforts.

This research aims to analyze the feasibility of municipal waste reuse for designing vertical walls for ZEB inspired by one of the main Earthship principles. The Earthship concept is based on the extensive use of natural heat flow methods, and the arrangement of building materials to direct this passive energy from the earth to the building, without using machinery [12].

Moreover, Earthship is an autonomous building typology which utilizes passive solar principles, earth-sheltered design and "off-grid" energy systems and plants to provide the occupants with shelter, thermal comfort, food, water, electricity and wastewater treatment [13]. The Earthship concept was born in the early 1970s thanks to an experiment by Michael Reynolds who tried to reuse waste for designing building envelopes. Earth shelters have been defined as structures built with the use of earth masses against building walls, reducing heat losses and maintaining a steady indoor air temperature throughout the year [14].

Grindley and Hutchinson [15] analyzed the thermal behavior of an earth-sheltered building monitoring an Earthship in New Mexico and conducting some simulations for the UK climate; the obtained results indicated that this kind of building should require only a small amount of space heating during the winter. In addition, Al-Temeemi and Harris [16] stated that in hot-arid climates, adequate environmental strategies in building design are essential to minimize indoor cooling requirements.

Considering the adaptability of the Earthship model in European climates and contexts, simulations were conducted in five European climates, analyzing the thermal comfort of the global model Earthship [13].

Tires are the most used municipal waste in Earthship design for foundations or vertical walls, which are built with tires rammed with earth [15].

Another strategy for reducing energy consumption in Earthships is the use of operable windows to favor natural light indoors and ventilation to cool the building; moreover, the unobtrusive earth-sheltered structure minimizes visual impacts and the quality of sensitive sites [16].

In Europe, many Earthship constructions were realized from 2005 to 2010 as residential buildings in Valencia (Spain), Kernombre-Brittany (France), Skattungbyn Dalalarna (Sweden), Stronbeek Brabant (Belgium). In particular, a global model Earthship is conceived as an archetype that, with minor adaptations, can be realized in a wide variety of climates [17].

In view of these considerations, this research, coming from the Earthship's concept of waste reuse, has the aim to design and analyze a new building envelope structure for a passive house based on this Earthship principle and applied to urban contexts where building envelopes could be realized with local urban municipal waste in order to improve eco-friendly waste management at the local scale. Other Earthship principles, such as the generation of electricity onsite, water harvesting and management of sewage, have not been considered in this paper. This approach increases the environmental sustainability of the building sector not only by decreasing building energy needs, but also by reducing municipality waste thanks to its local reuse. These two aspects, building energy efficiency and municipal waste upcycling, are included in the main pillars of the smart cities concept [18-20]. Indeed, the energy performance certificate (EPC) in Italy also considers the environmental impact of buildings and materials, combining the energy consumption assessment [21] with the completeness of the green building analysis [22] or with a life cycle assessment (LCA) method for assessing the environmental impact of materials and plants over their life cycles $[23,24]$.

In particular, the main objective of the paper is to analyze thermal characteristics of municipal waste materials and reusing and assembling them in new building envelope structures properly 
designed by the authors. The analyzed materials have been previously used in Earthship homes both in Europe and in the USA, so their use is in compliance with international, European and American regulations for health and environmental protection issues.

Moreover, considering that all the designed structures respect the thermal transmittance limits of the European regulatory framework, the economic costs of the designed vertical walls have been compared with them and with a traditional envelope.

\section{Materials and Methods}

Different typologies of municipal waste have been analyzed considering the feasibility of their reuse for assembling building envelope structures able to respect the thermal transmittance limits imposed by the European regulatory framework. Indeed, analyzing the combinations of various materials is considered an effective method for designing external walls characterized by high energy performance for ZEB [25], considering that ZEB aims at reducing the energy demand through efficient technology measures [26]. In addition, the design of new building technologies upcycling municipal waste materials involves an additional reduction of environmental impacts [16], which decreases the waste amount to be treated thanks to local reuse.

The municipal wastes analyzed for designing energy efficient vertical walls are wood pallets, glass and plastic bottles, tires, and cardboard tubes. For each considered component, thermal transmittance and economic costs have been investigated.

According to the data of the Italian consortium of recycling and recovering packaging waste (COREPLA), the national quantities of waste generated per year and available for reuse are reported in Table 1.

Table 1. Potential reuse of the main municipal solid wastes.

\begin{tabular}{cccc}
\hline Material & Item & $\begin{array}{c}\text { Amounts Available for } \\
\text { Reuse (pieces/year) }\end{array}$ & $\begin{array}{c}\text { Amounts Available for } \\
\text { Reuse (t/year) }\end{array}$ \\
\hline Aluminium & Cans & $1,500,000,000$ & 67,500 \\
Paper & Packaging & - & $3,645,000$ \\
Rubber & Tires & $30,000,000$ & 500,000 \\
Wood & Pallet & $56,000,000$ & $1,401,900$ \\
Plastic & Bottles & $6,400,000,000$ & 256,000 \\
Glass & Bottles & $1,600,000,000$ & 512,000 \\
\hline
\end{tabular}

However, even if the amounts reported in Table 1 are available for reuse in waste collection points spread all over the Italian territory, most of them are usually recycled or used for producing energy, while only an undefined small percentage is reused.

Additionally, a specific analysis has been carried out in two Italian municipalities, Trevignano Romano and Ladispoli, both of them in the center of Italy, evaluating their intended uses, productive activities and waste amounts. Tables 2 and 3 summarize data coming from the Italian National Institute of Statistics (ISTAT), COREPLA and local waste treatment services.

All the municipal waste used for assembling building envelope structures requires a primary structure in which they perform as infill. A wooden structure of beams and pillars with metal joints has been selected in order to allow further reuses after the building is decommissioned.

In order to compare economic costs of the described wall structures characterized by similar energy efficiencies, they have been designed using different municipal wastes while maintaining for each structure a thermal transmittance (U) of about $0.25 \mathrm{~W} / \mathrm{m}^{2} \mathrm{~K}$, calculated according to UNI EN ISO 13790 on building thermal behavior. This baseline value has been selected since it allows the use of the assembled building envelope structures in all the Italian climate zones in compliance with the legal limits of the Italian building regulation also for years to come (Table 4). 
Table 2. Land uses and buildings' intended uses in the two analyzed municipalities.

\begin{tabular}{ccc}
\hline & Trevignano Romano & Ladispoli \\
\hline Total area (ha) & 1667 & 2580 \\
Forests and semi-natural areas & 390 & 160 \\
Agricultural areas & 936 & 1830 \\
Artificial surfaces & 340 & 590 \\
Population & 5657 & 37,473 \\
Overall buildings & 1629 & 4383 \\
Housing units & $80 \%$ & $84.5 \%$ \\
Public buildings & $2 \%$ & $1.5 \%$ \\
Commercial activities & $18 \%$ & $14 \%$ \\
Farms and livestock & 17 & 11 \\
Wholesale & 13 & 103 \\
Retail & 112 & 488 \\
Construction companies & 5 & 29 \\
Auto industry & 8 & 45 \\
Textile companies & 0 & 55 \\
Printing & 0 & 4 \\
Catering activities & 49 & 225 \\
\hline
\end{tabular}

Table 3. Quantities of waste by type in tons per year.

\begin{tabular}{cccc}
\hline & Italy & Trevignano Romano & Ladispoli \\
\hline Cardboard tubes & Not available & 0 & $21 \mathrm{t} /$ year \\
Tires & $500,000 \mathrm{t} /$ year & $18 \mathrm{t} /$ year & $101 \mathrm{t} /$ year \\
Cans & $67,500 \mathrm{t} /$ year & $38 \mathrm{t} /$ year & $38 \mathrm{t} /$ year \\
Glass bottles & $512,000 \mathrm{t} /$ year & $224 \mathrm{t} /$ year & $260 \mathrm{t} /$ year \\
Plastic bottles & $256,000 \mathrm{t} /$ year & $100 \mathrm{t} /$ year & $206 \mathrm{t} /$ year \\
Pallet & $1,401,900 \mathrm{t} /$ year & $103.4 \mathrm{t} /$ year & $444.4 \mathrm{t} /$ year \\
\hline
\end{tabular}

Table 4. Transmittance limits in $\left(\mathrm{W} / \mathrm{m}^{2} \mathrm{k}\right)$ for each climate zone according to the Italian Ministerial Decree, 26 June 2015.

\begin{tabular}{ccc}
\hline Climate Zone & U Limit (2015) & U Limit (2019-2022) \\
\hline A and B & 0.45 & 0.43 \\
C & 0.38 & 0.34 \\
D & 0.34 & 0.29 \\
E & 0.30 & 0.25 \\
F & 0.28 & 0.25 \\
\hline
\end{tabular}

The energy performance and, consequentially, the economic costs of the analyzed building components can change by varying the thickness of the insulating layer, by changing the insulation type or by using a further overcoat layer [27].

Considering the thermal resistances of indoor and outdoor air film surfaces, the values have been estimated considering the reciprocals of indoor and outdoor adduction coefficients taking into account convective and radiative heat transfer [28]. Additionally, the thermal conductivity for all the considered materials has been obtained by consulting the database of the Italian Heating Engineering Committee-Energy and the Environment (CTI) of the Italian National Unification (UNI).

Thermal bridges between the different types of structures have not been considered since the use of Oriented Strand Board (OSB) panels in the surfaces of each model makes heat transfer uniform.

Lastly, the thickness of the materials used in the thermal calculations has been assessed considering the most common waste available at the Trevignano Romano and Ladispoli local waste treatment services. 


\subsection{Cardboard Tube Reuse}

Cardboard tubes have been used for designing energy-efficient vertical walls elaborating a model structure composed by 35 cardboard tubes which dimensions are $0.60 \mathrm{~m}$ (length) and 0.43 (thickness). The designed structure is composed by 4 layers: one OSB (Oriented strand board) panel for each wall surface, cardboard tubes filled with granulated cork, and rammed earth cardboard tubes (Figure 1).

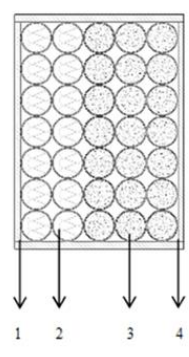

(a)
1) OSB panel $0.015 \mathrm{~m}$ 2) Cardboard tubes with insulating $0.08 \mathrm{~m}$ 3) Cardboard tubes rammed earth $0.08 \mathrm{~m}$ 4) OSB panel $0.015 \mathrm{~m}$

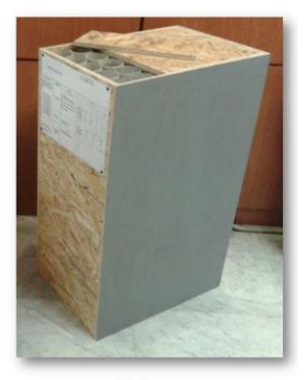

(b)

Figure 1. (a) Section of vertical wall with cardboard tubes; (b) Vertical wall model with cardboard tubes prototype.

Cardboard tube models are not load-bearing and require a primary structure in which they perform as infill. In particular, they are assembled with metal junctions.

\subsection{Tire Reuse}

The second vertical wall structure with a thermal transmittance of $0.25 \mathrm{~W} / \mathrm{m}^{2} \mathrm{~K}$ was designed reusing tires. The model is composed of four tires filled with compressed straw (Figure 2).
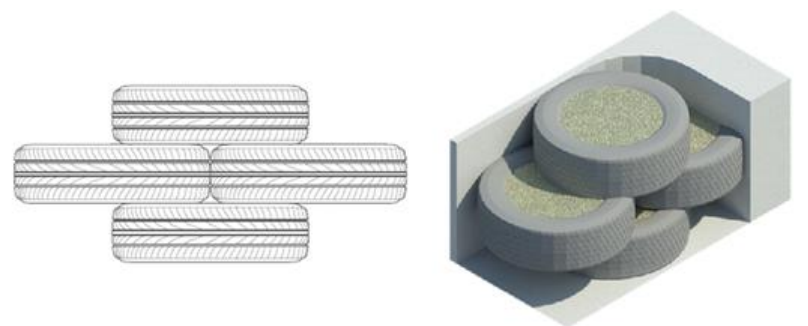

Figure 2. Section and 3D view of a model using four tires.

The model includes two layers of eco-friendly lime plaster on the external and internal surfaces; the total thickness of the structure is about $40 \mathrm{~cm}$ considering common tire dimensions (Figure 3).

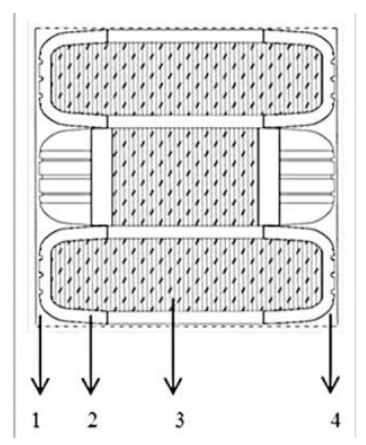
1) Eco-friendly lime plaster $(0.015 \mathrm{~m})$
2) Tires $(0.025 \mathrm{~m})$
3) Compressed straw $(0.32 \mathrm{~m})$
4) Eco-friendly lime plaster $(0.015 \mathrm{~m})$

Figure 3. Section of vertical wall with tires. 


\subsection{Plastic and Glass Bottle Reuse}

Plastic bottles have been reused to design a vertical wall model composed by 49 a litre bottles in horizontal position, filled with hemp fiber, and 27 half litre bottles in vertical position, filled with sand. The total thickness of this model is $0.45 \mathrm{~m}$ and OSB panels have been used on both sided of the structure, as for the above-described cardboard tubes model (Figures 4 and 5).

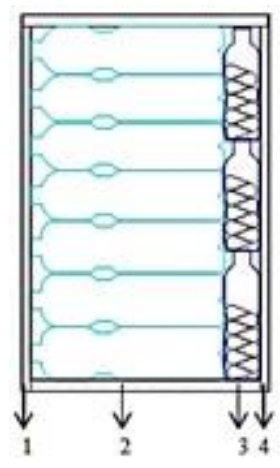

1) OSB panel $0.015 \mathrm{~m}$

2) a litre and half plastic bottles filled with sand $0.3 \mathrm{~m}$

3) half a litre bottle filled with insulating $0.12 \mathrm{~m}$

4) OSB panel $0.015 \mathrm{~m}$

Figure 4. Section of plastic bottles model.

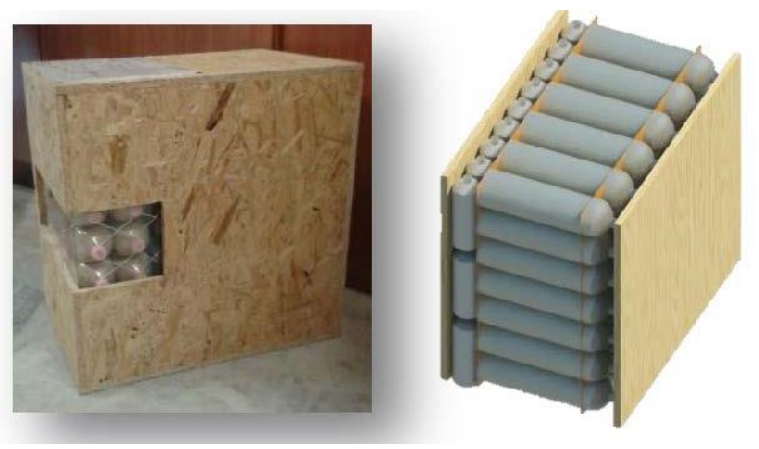

Figure 5. Vertical wall model with plastic bottles prototype and 3D view.

Another model for vertical walls has been realized using 21 glass bottles of 0.75 liters each, laid in horizontal position and covered by eco-friendly lime plaster (Figure 6). Glass bottles are the only waste component stabilized with cement mortar since glass and cement mortar are both composed of silica and during the decommissioning phase it is not necessary to separate these two components.

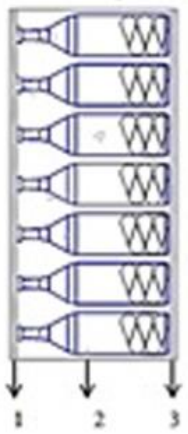

1) eco-friendly lime plaste

2) 0.75 litre glass bottles filled with a 0.08 sheep wool layer

3) eco-friendly lime plaster

(a)

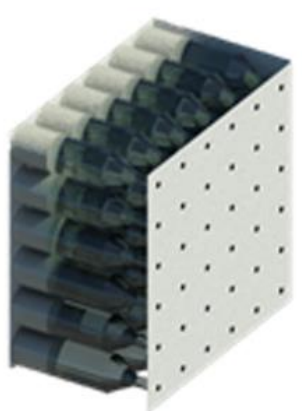

(b)

Figure 6. (a) Section of vertical wall with glass bottles; (b) Vertical wall model with glass bottles $3 \mathrm{D}$ view. 


\subsection{Wood Pallet Reuse}

The last municipal waste considered for designing an eco-friendly building envelope structure is wood pallets, which are the most common and cheap wood structure to reuse among urban waste. A 17-cm-thick model has been realized using two pallets and two OSB panels. The model has been insulated to get a $0.25 \mathrm{~W} / \mathrm{m}^{2} \mathrm{~K}$ thermal transmittance filling in the two wood pallets with sheep wool (Figure 7).

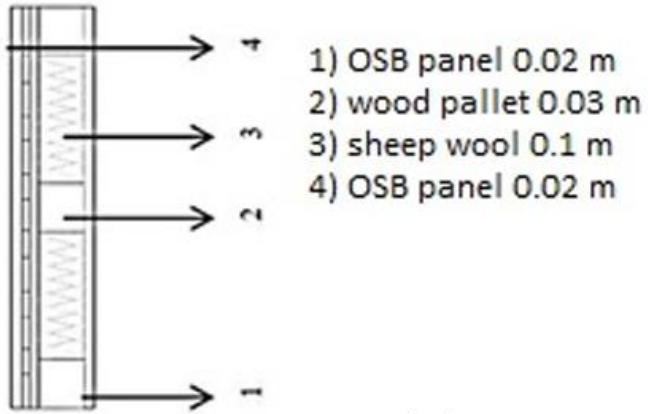

(a)

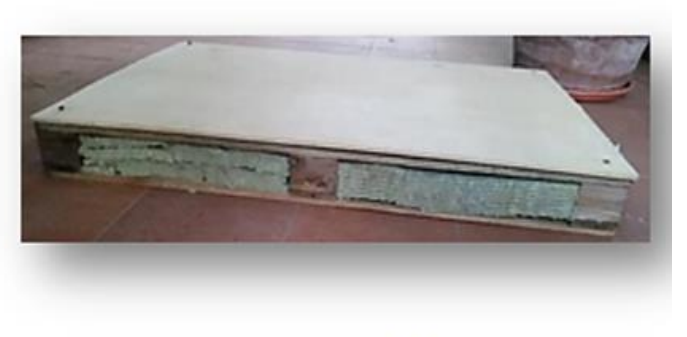

(b)

Figure 7. (a) Section of wood pallets model; (b) Wood pallets model prototype.

\section{Results}

The thermal transmittance of the designed building envelope structures reusing municipal waste has been assessed according to UNI EN ISO 13790 on building thermal behavior. The results obtained are summarized in Tables 5-9. In the tires model, a double thickness of tire carcass has been considered (at the internal and external side of the component), while the air resistance factor has been omitted since it is irrelevant in the calculation of the total thermal transmittance mainly due to the compressed straw conductivity and thickness.

Table 5. Thermal performance of vertical wall reusing cardboard tubes $\left(\mathrm{U}=0.25 \mathrm{~W} / \mathrm{m}^{2} \mathrm{~K}\right)$.

\begin{tabular}{cccc}
\hline Layer & Thickness $(\mathbf{m})$ & $\begin{array}{c}\text { Thermal Conductivity } \\
\lambda(\mathbf{W} / \mathbf{m} \mathbf{K})\end{array}$ & $\begin{array}{c}\text { Thermal Resistance } \\
\mathbf{R}\left(\mathbf{m}^{\mathbf{2}} \mathbf{K} / \mathbf{W}\right)\end{array}$ \\
\hline Indoor air film surface & & & 0.125 \\
OSB Panel & 0.015 & 0.13 & 0.12 \\
Cardboard tubes rammed with earth & 0.24 & 0.9 & 0.267 \\
Cardboard tubes with granulated cork & 0.16 & 0.049 & 3.325 \\
OSB Panel & 0.015 & 0.13 & 0.12 \\
Outdoor air film surface & & & 0.043 \\
\hline
\end{tabular}

Table 6. Thermal performance of vertical wall reusing tyres $\left(\mathrm{U}=0.25 \mathrm{~W} / \mathrm{m}^{2} \mathrm{~K}\right)$.

\begin{tabular}{cccc}
\hline Layer & Thickness $(\mathbf{m})$ & $\begin{array}{c}\text { Thermal Conductivity } \\
\lambda(\mathbf{W} / \mathbf{m K})\end{array}$ & $\begin{array}{c}\text { Thermal Resistance } \\
\mathbf{R}\left(\mathbf{m}^{\mathbf{2}} \mathbf{K} / \mathbf{W}\right)\end{array}$ \\
\hline Indoor air film surface & & & 0.125 \\
Ecological plaster in lime & 0.015 & 0.7 & 0.021 \\
Tyres & 0.05 & 0.192 & 0.260 \\
Straw compresses & 0.32 & 0.09 & 3.528 \\
Ecological plaster in lime & 0.015 & 0.7 & 0.021 \\
Outdoor air film surface & & & 0.043 \\
\hline
\end{tabular}


Table 7. Thermal performance of vertical wall reusing plastic bottles $\left(\mathrm{U}=0.25 \mathrm{~W} / \mathrm{m}^{2} \mathrm{~K}\right)$.

\begin{tabular}{cccc}
\hline Layer & Thickness $\mathbf{( m )}$ & $\begin{array}{c}\text { Thermal Conductivity } \\
\lambda(\mathbf{W} / \mathbf{m K})\end{array}$ & $\begin{array}{c}\text { Thermal Resistance } \\
\mathbf{R}\left(\mathbf{m}^{\mathbf{2}} \mathbf{K} / \mathbf{W}\right)\end{array}$ \\
\hline Indoor air film surface & & & 0.125 \\
OSB Panel & 0.015 & 0.13 & 0.12 \\
1.5 litre plastic bottles filled with sand & 0.30 & 0.35 & 0.86 \\
0.5 litre plastic bottles filled with hemp fibre & 0.12 & 0.044 & 2.732 \\
OSB Panel & 0.015 & 0.13 & 0.12 \\
Outdoor air film surface & & & 0.043 \\
\hline
\end{tabular}

Table 8. Thermal performance of vertical wall reusing glasses bottles $\left(\mathrm{U}=0.259 \mathrm{~W} / \mathrm{m}^{2} \mathrm{~K}\right)$.

\begin{tabular}{cccc}
\hline Layer & Thickness $\mathbf{( m )}$ & $\begin{array}{c}\text { Thermal Conductivity } \\
\lambda(\mathbf{W} / \mathbf{m K})\end{array}$ & $\begin{array}{c}\text { Thermal Resistance } \\
\mathbf{R}\left(\mathbf{m}^{\mathbf{2}} \mathbf{K} / \mathbf{W}\right)\end{array}$ \\
\hline Indoor air film surface & & & 0.125 \\
\hline Eco-friendly lime plaster & 0.015 & 0.7 & 0.021 \\
\hline 0.75 litre empty glass bottles & 0.09 & 0.14 & 0.64 \\
\hline 0.75 litre glass bottles filled with polyurethane & 0.09 & 0.03 & 0.021 \\
\hline Eco-friendly lime plaster & 0.015 & 0.7 & 0.043 \\
\hline Outdoor air film surface & & &
\end{tabular}

Table 9. Thermal performance of foundation structure reusing wood pallets $\left(\mathrm{U}=0.25 \mathrm{~W} / \mathrm{m}^{2} \mathrm{~K}\right)$.

\begin{tabular}{cccc}
\hline Layer & Thickness $(\mathbf{m})$ & $\begin{array}{c}\text { Thermal Conductivity } \\
\lambda(\mathbf{W} / \mathbf{m K})\end{array}$ & $\begin{array}{c}\text { Thermal Resistance } \\
\mathbf{R}\left(\mathbf{m}^{\mathbf{2}} \mathbf{K} / \mathbf{W}\right)\end{array}$ \\
\hline Indoor air film surface & & & 0.125 \\
OSB Panel & 0.015 & 0.13 & 0.115 \\
Wood pallet & 0.03 & 0.126 & 0.238 \\
Insulation (polyurethane) & 0.10 & 0.03 & 3.33 \\
OSB Panel & 0.015 & 0.13 & 0.115 \\
Outdoor air film surface & & & 0.043 \\
\hline
\end{tabular}

The economic costs of the above-described building envelope structures have been assessed and compared with a common building wall structure $(1.5 \mathrm{~cm}$ of plaster, $8 \mathrm{~cm}$ of perforated brick, $12 \mathrm{~cm}$ of insulating material, $12 \mathrm{~cm}$ of perforated brick,) with the same thermal transmittance (Table 10), consulting a traditional price list for common building materials [29].

Table 10. Thermal performance of a common building wall structure $\left(\mathrm{U}=0.24 \mathrm{~W} / \mathrm{m}^{2} \mathrm{~K}\right)$.

\begin{tabular}{cccc}
\hline Layer & Thickness $(\mathbf{m})$ & $\begin{array}{c}\text { Thermal Conductivity } \\
\lambda(\mathbf{W} / \mathbf{m K})\end{array}$ & $\begin{array}{c}\text { Thermal Resistance } \\
\mathbf{R}\left(\mathbf{m}^{\mathbf{2}} \mathbf{K} / \mathbf{W}\right)\end{array}$ \\
\hline Indoor air film surface & & & 0.125 \\
Gypsum plaster & 0.015 & 0.7 & 0.02 \\
Perforated brick & 0.08 & 0.36 & 0.22 \\
Extruded polystyrene in lime & 0.12 & 0.035 & 3.43 \\
Perforated brick & 0.12 & 0.36 & 0.33 \\
Outdoor air film surface & & & 0.043 \\
\hline
\end{tabular}

The economic costs of the designed building envelope structures have been estimated for each model consulting the Italian consortiums dealing with the reuse and recycle of tires (Ecopneus), papers and cartons (Comieco), wood (Rilegno), plastic (Corepla) and glass (Coreve).

Then, since each model has different dimensions, a parametric cost per square meter has been evaluated (Table 11 and Figure 8). Indeed, in Italy the price of waste is determined by the consortia depending on local taxes and the recycling process used in the considered municipality. 
In particular, Table 11 and Figure 8 values have been assessed for the pilot municipalities of Ladispoli and Trevignano Romano.

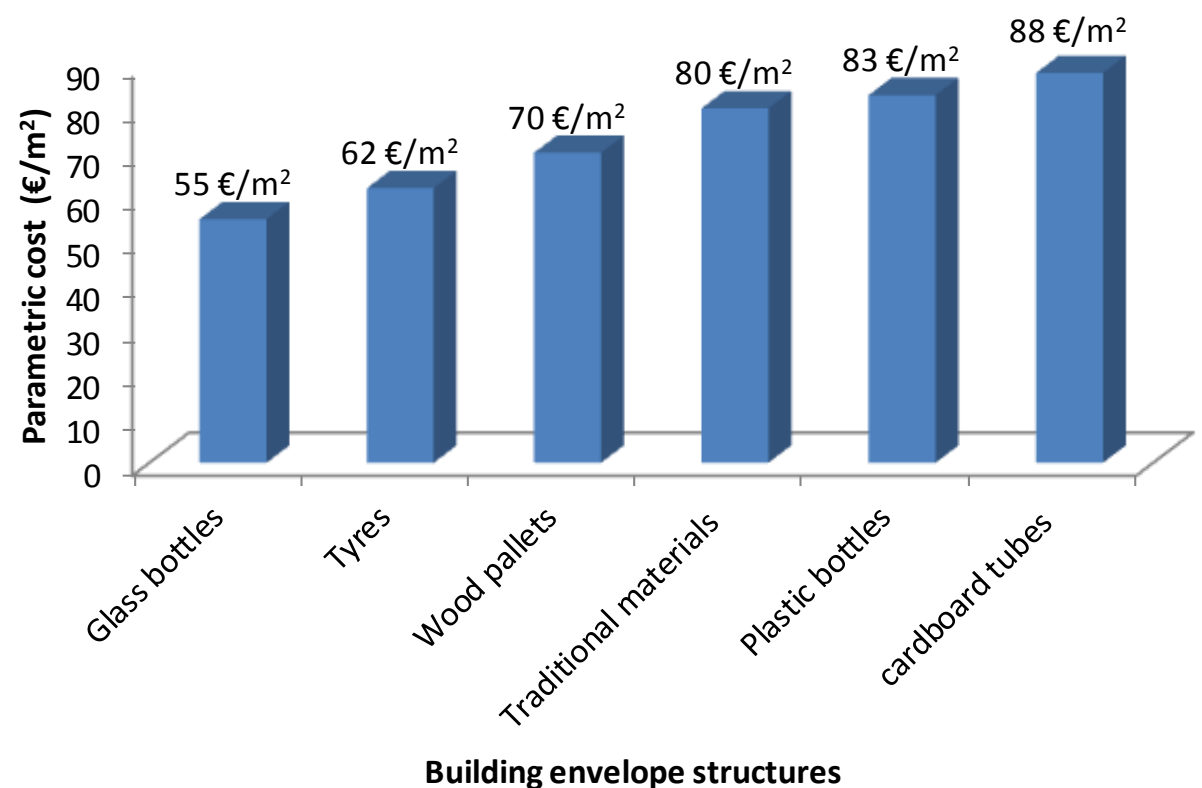

Figure 8. Parametric costs of each considered building envelope structure $\left(€ / \mathrm{m}^{2}\right)$.

Table 11. Dimensions and economic costs of each designed model.

\begin{tabular}{cccc}
\hline Designed Model & Dimension $\left(\mathbf{m}^{\mathbf{2}}\right)$ & Cost $(\boldsymbol{(})$ & Parametric Cost $\left(\boldsymbol{\epsilon} / \mathbf{m}^{\mathbf{2}}\right)$ \\
\hline Glass bottles & 0.192 & $10.56 €$ & $55 €$ \\
Tires & 0.65 & $40.30 €$ & $62 €$ \\
Wood pallets & 0.96 & $67.20 €$ & $70 €$ \\
Plastic bottles & 0.384 & $31.87 €$ & $83 €$ \\
cardboard tubes & 0.7 & $61.60 €$ & $88 €$ \\
\hline
\end{tabular}

Maintenance costs have not been considered since these kinds of interventions only affect external plasters while internal components do not need any required intervention. However, the internal components of the elaborated models could be damaged by substantial seismic events which may require the replacement of all components, leaving intact the wood-bearing structure.

The cost for handling the materials is included in the cost comparison since each model does not weigh more than $50 \mathrm{Kg}$ and therefore it can be handled manually by two workers without spending money on cranes.

The thermal transmittance being equal, the results obtained highlight that the building envelope structure reusing glass bottles is the cheaper option. Structures reusing tires and wood pallets are cheaper than traditional ones, while plastic bottle and cardboard tube structures are more expensive, but obviously all the structures realized reusing municipal waste have an essential added environmental sustainability value compared to traditional structures due to the municipal waste virtuous circle optimization.

\section{Conclusions}

This paper proposes the reuse and upcycling of municipal waste materials for designing new energy efficient building envelope structures, underlining their economic feasibility. The elaborated structures could be used by designers and architects for the planning of passive and eco-friendly buildings in urban areas. In particular, all the considered municipal waste could be easily reused for 
the realizations of building structures needed in urban areas close to the landfills where these materials are available.

The intended target groups are mainly construction companies. The building typology depends on the selected bearing structure; using wood, the elaborated models could be used for no more than three-story residential or service buildings. These kinds of buildings may be particularly suitable for areas under environmental constraints since they are easily removable and improve the upcycling of local waste. Indeed, the local reuse of these materials for energy efficient building structure design without particular treatments is an effective, low-cost and environmentally sustainable waste management strategy that avoids the usual recycling processes.

Comparing the economic costs of the new building envelope structures, the obtained results highlight their economic feasibility compared to traditional structures with the same overall thermal transmittance. Consequentially, municipal waste could be locally reused for building envelope structures, guaranteeing the same thermal performance with similar or lower economic costs. Their use depends on the materials' availability in a considered urban area and involves a decrease of the building sector energy demand, improving, at the same time, sustainable waste management at the local scale.

The planned buildings could be implemented with other Earthship sustainable strategies and technologies, such as thermal solar, photovoltaics panels and windmills for electricity, heating and cooling systems, as well as water harvesting systems and solar greenhouse design.

The experience of residents and the environmental impacts will be evaluated in a pilot building that will be realized by September 2016 and will be analyzed in a future study.

Author Contributions: All authors contributed equally in the writing of this paper. All authors have read and approved the final manuscript.

Conflicts of Interest: The authors declare no conflict of interest.

\section{References}

1. European Parliament. Directive 2010/31/EU of the european parliament and of the council on the energy performance of buildings (EPBD). Off. J. Eur. Union 2010, 12, 124-146.

2. Burattini, C.; Nardecchia, F.; Bisegna, F.; Cellucci, L.; Gugliermetti, F.; de Lieto Vollaro, A.; Salata, F.; Golasi, I. Methodological Approach to the Energy Analysis of Unconstrained Historical Buildings. Sustainability 2015, 7, 10428-10444. [CrossRef]

3. Nastasi, B.; de Santoli, L.; Albo, A.; Bruschi, D.; Lo Basso, G. RES (Renewable Energy Sources) availability assessments for Ecofuels production at local scale: Carbon avoidance costs associated to a hybrid biomass/H2NG-based energy scenario. Energy Procedia 2015, 81, 1069-1076. [CrossRef]

4. De Santoli, L.; Lo Basso, G.; Bruschi, D. Hybrid system with an integrated CHP plant fueled by H2NG blends: Theoretical energy-environmental analysis and foreseeable optimizations. Energy Build. 2014, 71 , 88-94. [CrossRef]

5. de Santoli, L.; Lo Basso, G.; Bruschi, D. Energy characterization of CHP (combined heat and power) fuelled with hydrogen enriched natural gas blends. Energy 2013, 60, 13-22. [CrossRef]

6. De Santoli, L.; Lo Basso, G.; Bruschi, D. A small scale H2NG production plant in Italy: Techno-economic feasibility analysis and costs associated with carbon avoidance. Int. J. Hydrog. Energy 2014, 39, 6497-6517. [CrossRef]

7. Nastasi, B. Renewable hydrogen potential for low-carbon retrofit of the building stocks. Energy Procedia 2015, 82, 944-949. [CrossRef]

8. Lo Basso, G.; de Santoli, L.; Albo, A.; Nastasi, B. H2NG (hydrogen-natural gas mixtures) effects on energy performances of a condensing micro-CHP (combined heat and power) for residential applications: An expeditious assessment of water condensation and experimental analysis. Energy 2015, 84, 397-418. [CrossRef]

9. De Santoli, L.; Mancini, F.; Nastasi, B.; Piergrossi, V. Building integrated bioenergy production (BIBP): Economic sustainability analysis of Bari airport CHP (combined heat and power) upgrade fueled with bioenergy from short chain. Energy 2015, 81, 499-508. [CrossRef] 
10. Hernandez, P.; Kenny, P. From net energy to zero energy buildings: Defining life cycle zero energy buildings (LC-ZEB). Energy Build. 2010, 42, 815-821. [CrossRef]

11. Panagiotidou, M.; Fuller, R.J. Progress in ZEBs-A review of definitions, policies and construction activity. Energy Policy 2013, 62, 196-206. [CrossRef]

12. Akubue Jideofor, A. Passive annual heat storage principles in earth sheltered housing, a supplementary energy saving system in residential housing. Energy Build. 2008, 40, 1214-1219.

13. Freney, M.; Soebarto, V.; Williamson, T. Thermal comfort of global model earthship in various european climates. In Proceedings of the 13th Conference of International Building Performance Simulation Association, Chambéry, France, 26-28 August 2013; pp. 1625-1632.

14. Akubue Jideofor, A. Earth Shelters; A Review of Energy Conservation. Properties in Earth Sheltered Housing; InTech: Rijeka, Croatia, 2012; Available online: http:/ /dx.doi.org/10.5772/51873 (accessed on 22 June 2016).

15. Grindley, P.C.; Hutchinson, M. The Thermal Behaviours of an Earthship; Cranfield University: Cranfield, UK, 1996; pp. 154-159.

16. Al-Temeemi, A.A.; Harris, D.J. A guideline for assessing the suitability of earth-sheltered mass-housing in hot-arid climates. Energy Build. 2004, 36, 251-260. [CrossRef]

17. Freney, M.; Soebarto, V.; Williamson, T. Earthship monitoring and thermal simulation. Archit. Sci. Rev. 2013, 56, 208-219. [CrossRef]

18. Mattoni, B.; Gugliermetti, F.; Bisegna, F. A multilevel method to assess and design the renovation and integration of Smart Cities. Sustain. Cities Soc. 2015, 15, 105-119. [CrossRef]

19. Mattoni, B.; Pagliaro, F.; Gugliermetti, L.; Bisegna, F.; Cellucci, L. A territorial based strategy for the distribution of sensor networks in smart cities. In Proceedings of the IEEE 15th International Conference on Environment and Electrical Engineering, Rome, Italy, 10-13 June 2015; pp. 653-658.

20. Kylili, A.; Fokaides, P.A. European smart cities: The role of zero energy buildings. Sustain. Cities Soc. 2015, 15, 86-95. [CrossRef]

21. De Santoli, L.; Di Matteo, U. Building Energy and Environment Performance System (BEEPS): A programme for building energy certification in Italy. Build. Serv. Eng. Res. Technol. 2003, 24, 61-68. [CrossRef]

22. Pagliaro, F.; Cellucci, L.; Burattini, C.; Bisegna, F.; Gugliermetti, F.; de Lieto Vollaro, A.; Salata, F.; Golasi, I. A Methodological Comparison between Energy and Environmental Performance Evaluation. Sustainability 2015, 7, 10324-10342. [CrossRef]

23. Astiaso Garcia, D.; Di Matteo, U.; Cumo, F. Selecting Eco-Friendly Thermal Systems for the "Vittoriale Degli Italiani" Historic Museum Building. Sustainability 2015, 7, 12615-12633. [CrossRef]

24. Monaco, A.; Di Matteo, U. Life cycle analysis and cost of a molten carbonate fuel cell prototype. International Journal of Hydrogen. Energy 2011, 36, 8103-8111.

25. Baglivo, C.; Congedo, P.M.; Fazio, A.; Laforgia, D. Multi-objective optimization analysis for high efficiency external walls of zero energy buildings (ZEB) in the Mediterranean climate. Energy Build. 2014, 84, 483-492. [CrossRef]

26. Justo Alonso, M.; Liu, P.; Mathisen, H.M.; Ge, G.; Simonson, C. Review of heat/energy recovery exchangers for use in ZEBs in cold climate countries. Build. Environ. 2015, 84, 228-237. [CrossRef]

27. Cumo, F.; Pennacchia, E.; Sferra, A. Uso, Riuso, Disuso. Criteri e Modalità per il Riuso dei Rifiuti Come Materiale per L'edilizia, 1st ed.; Franco Angeli Edizioni: Roma, Italia, 2015; p. 220.

28. Tabares-Velasco, P.C.; Srebric, J. A heat transfer model for assessment of plant based roofing systems in summer conditions. Build. Environ. 2012, 49, 310-323. [CrossRef]

29. DEI. Prezzi Informativi Dell'edilizia. Nuove Costruzioni. Materiali ed Opere Compiute, 4th ed.; DEI Tipografia del Genio Civile: Roma, Italia, 2015.

(C) 2016 by the authors; licensee MDPI, Basel, Switzerland. This article is an open access article distributed under the terms and conditions of the Creative Commons Attribution (CC-BY) license (http://creativecommons.org/licenses/by/4.0/). 